\title{
(Not So) Monumental Agents: De/Colonizing Places of Learning
}

\author{
Marc Higgins \\ Department of Secondary Education \\ Faculty of Education \\ University of Alberta \\ marc1@,ualberta.ca \\ Brooke Madden \\ Department of Educational Policy Studies \\ Faculty of Education \\ University of Alberta \\ bmadden@ualberta.ca
}

What might it mean to inflect the current focus on public memory encapsulated in monuments by considering an equally important yet more subtle or (not so) monumental agent: educational institutions as products and producers of colonial logics and ways of being in relationship? In this essay, the authors offer pedagogical orientations that seek to embed curriculum in a multiplicity of colonial here-nows and there-thens that always already constitute our places of learning and learning selves in the making.

Thought is able to confront us from the only place where it can confront us: from outside the concepts we already have, outside the subjectivities we already are, outside the material reality we already know. (Ellsworth, 2005, p. 55)

In light of calls to address explicitly lingering and momentous celebrations of white settler nationalism - perhaps most recently made visible through the events surrounding the proposed removal of the Robert E Lee statue in Charlottesville and the related "Unite the Right" rally and protests - we take up the invitation to explore the roles we might play as teacher educators specializing in Indigenous education and truth and reconciliation education. Without diminishing (re)naming efforts that seek to address appropriation of Indigenous symbols (e.g., UBC, n.d.) and celebration of public figures who played key roles in the "cultural genocide" (TRC, 2015) of Indigenous peoples (e.g., Clancy, 2017; Wherry, 2017) for example, we suggest decolonizing education involves attending to a much more expansive and insidious landscape. Accordingly, we inflect the focus on public memory encapsulated in (and produced through) monuments by considering an equally important yet more subtle or (not so) monumental agent: educational institutions. While we hold that is imperative to vigilantly engage in the refusal, resistance, and resignification of historical moments of racism and colonialism and the ways in which they materially manifest, we suggest that these mo(nu)ments are also components of greater movements (i.e., relations of power that flow directionally, vary in intensity, and sometimes sediment). They are at once a moment and a movement: a "mo(ve)ment" (Davies \& Gannon, 2009). Mo(ve)ment calls attention to the ways in which colonial logics (Donald, 2012) and the types of relationships they secure (Dion, 2009) exceed a series of mo(nu)ments that geographically and historically perforate the fabric of society. Beyond a symbolic node, mo(ve)ment includes the material-discursive force within, between, and beyond these 
mo(nu)ments that gives shape and texture to the spaces and places we occupy, as well as manifests as acts of everyday racism and colonialism.

As nodes within a flow, mo(nu)ments are not hermetically sealed from that which is temporally and spatially adjacent, nor are they separate or separable from that which semiotically and materially co-constitutes them. Just as a colonial past implicates us as humans in the present and to futures-to-come (Donald, 2004), we argue that colonial logics are also distributed across the materiality and spatiality of place. As such, our places of learning come to shape both what and how we learn about and imagine Indigenous - non-Indigenous relations. "Thinking with" (Jackson \& Mazzei, 2012) Ellsworth's (2005) scholarship on place and pedagogy, we ask: How might we design pedagogical approaches that invite differential consideration of our places of learning or "the material reality we already know" so that "thought might be able to confront us" (p. 55, emphasis ours)? In particular, we attend to the subtle and enduring ways that places of learning and their facets (e.g., architecture) pedagogically present de/colonizing possibilities and problematics. De/colonizing underscores the complexity of the material-discursive structures, commitments, and practices of educational institutions and the Indigenizing initiatives they pursue. It suggests that decolonization need not be (and conceivably cannot be) constructed in neat opposition to colonization, and calls for consistent examination of colonial logics and productions that seep into hybrid colonizing and decolonizing contexts (Madden \& McGregor, 2013; Higgins, 2014).

Although "these places of learning speak with a voice that is so different from our own as educators" (Ellsworth, 2005, p. 10), considering educational institutions as not only places in which learning happens but also from which we learn is significant. Thinking with Ellsworth (2005) invites a (re)consideration of places of learning as more than "texts" to be hermeneutically interpreted by learners; they are also teaching agents. Marker (2006) inspires us to challenge the notion that educational institutions "seem to arrive on the landscape out of nowhere. They are institutions plopped down in a place without regard to the local history or ecology of the land" (p. 492). In our respective pedagogical approaches we endeavour to disrupt the taken-for-granted notion that education is placeless (see also Gruenewald, 2003) and challenge curriculum that does not account for (nor is accountable to) the place upon which it sits.

Thinking with Ellsworth (2005) invites analysis of the ways that educational institutions are always already placed and pedagogical: "architecture becomes pedagogical, pedagogy becomes architectural... together they create a fluid, moving pivot place that puts inside and outside, self and other, personal and social into relation" (Ellsworth, 2005, p. 38). In our respective coursework, we invite students to tactically wander with/in our university campus while attending to how (not so) monumental agents enfold a here-now with a multiplicity of there-thens. We agree that educational institutions are often "founded on a vision and visualization of education and culture that look to Europe as the center of all knowledge and civilization" (Battiste et al., 2005, p. 8). As teacher educators, we seek to reveal the "Eurocentric curriculum... hidden in plain view" (Battiste et al., 2005, p. 8) in the very architecture and adornments of our places of learning. This often unnoticed pedagogical force, while totalizing, is never fully totalized: place always has the "capacity to both usurp variation and express potential" (Ellsworth, 2005, p. 130) 
Below, we offer three pedagogical orientations for attending to (not so) monumental agents and the production of de/colonizing places of learning and learning selves in the making.

1. Producing. To engage with a curriculum of place hidden in plain view, we suggest that learners must dislodge and reconfigure what is already known and know-able (e.g., university campus as culturally neutral) through encounters that involve and interface their learning and "learning selves in the making" (Ellsworth, 2005, p. 56). For example, we draw on pedagogical modes that attend to and are themselves literal mo(ve)ments: a "doubled action... of dwelling in and on particular moments of being, and of movement toward, or openness to, new possibilities both of seeing and of being" (Davies \& Gannon, 2009 , p. 9). For us, this includes approaches that are aesthetic, embodied, and relational like tactical wandering (see orientation \#2 and Higgins, 2016) and photography. These characteristics not only signal 'learning' but also implicate the learner in knowledge production of place and self through subjective meaning-making.

2. Processing. "Like all systems and structures of address, pedagogy is unable to contain or control where and when its address arrives or how it is taken up" (Ellsworth, 2005, p. 5455). This phenomena is intensified with open-ended pedagogical "texts" such as place that can produce a (sometimes overwhelming) multiplicity of possible experiences. A schematic cue is necessary in orienting meaning making towards curricular goals, de/colonizing in our case. Wandering becomes tactical through inflecting but not restricting the learning (selves) in the making. For example, in a truth and reconciliation education course offered in July 2017, Brooke offered "celebration and contestation of Canada $150 "$ as a schematic cue to draw students attention to the ways in which dominant colonial discourses manifest and are subverted on the University of Alberta North Campus.

3. (Re)Presenting. We endeavour to increase the potency of producing and processing through students creating a representation of their unique experiences. For example, Marc asks students to select and submit one photograph along with an artist's statement that outlines what they are attempting to capture, aesthetic/creative/artistic choices they are making, and how they are responding to the schematic cue. Photographs and statements are curated by the instructor and students participate in a gallery walk. We have found that lingering with and articulating experience through representation creates the conditions where the mo(ve)ment of pedagogy might register upon the learning body. We have witnessed examples whereby experience appears to gain a meaningful temporality and relation to the learning self in the making, as well as produces the differential emergence of de/colonizing subjectivities. Further, (re)presenting creates the (probable) possibility of a de/colonizing curriculum of place circulating beyond the immediacy of that learning self. If places of learning always already work to re-center and naturalize colonial logics and their relationships through their material-discursive structure, then there is a need to take an active role in refusing, resisting, disrupting, or displacing these (not so) monumental agents.

\footnotetext{
${ }^{1}$ Wandering that is guided by this schematic cue is inspired by Kerr's (2017) scholarship that theorizes teacher candidates' processes of negotiating tension between national celebrations and corresponding contestations.
} 
In conclusion, we agree that monumental testaments to white settler nationalism are significant sites to contest. Moreover, we re-iterate that colonial logics often transform these explicit and egregious examples into an elsewhere and elsewhen that do not implicate educators in a manner that illuminates the ways in which these systems operate in the here and now. Pedagogically, we wish to challenge a "curriculum of placelessness" (Donald, 2017) through offering pedagogical orientations to focus on our place of learning, the university campus. Particularly, we seek to expose its inextricable link to settler colonialism and its agency that is always already acting and producing, albeit often hidden in plain sight. Places of learning act as pivots that intensify the ways in which the learning self in the making comes to be shaped in and by colonial logics. Yet, because learning never occurs in the absence of place, place always offers pedagogical potentiality for de/colonizing: "architecture holds the potential for providing educators with material correlates of the moving, sensational experience of the learning self.... It holds the potential to produce spaces and times that are catalysts for rethinking pedagogy" (Ellsworth, 2005, p. 125).

\section{References}

Battiste, M., Bell, L., Findlay, I. M., Findlay, L., \& Henderson, J. Y. (2005). Thinking place: Animating the Indigenous humanities in education. Australian Journal of Indigenous Education, 34, 7-19.

Clancy, C. (2017, August 25). Edmonton rally pushes to erase tributes to historical figure Frank Oliver. Edmonton Journal. Retrieved from http://edmontonjournal.com/news/localnews/edmonton-rally-pushes-to-erase-tributes-to-historical-figure-frank-oliver

Davies, B., \& Gannon, S. (2009). Pedagogical encounters. New York, NY: Peter Lang.

Dion, S. D. (2009). Braiding histories: Learning from Aboriginal peoples' experiences and perspectives. Vancouver, Canada: UBC Press.

Donald, D. T. (2004). Edmonton pentimento: Re-Reading history in the case of the Papaschase Cree. Journal of the Canadian Association for Curriculum Studies, 2(1), 21-54.

Donald, D. (2012). Indigenous Métissage: A decolonizing research sensibility. International Journal of Qualitative Studies in Education, 25(5), 533-555.

Donald, D. (2017, January). Place. Lecture conducted from The Centennial Centre for Interdisciplinary Science, University of Alberta, Edmonton.

Ellsworth, E. (2005). Places of learning: Media, architecture, pedagogy. New York, NY: Routledge.

Gruenewald, D. A. (2003). The best of both worlds: A critical pedagogy of place. Educational researcher, 32(4), 3-12.

Jackson, A. Y., \& Mazzei, L. (2012). Thinking with theory in qualitative research: Viewing data across multiple perspectives. New York, NY: Routledge.

Higgins, M. (2014). De/colonizing pedagogy and pedagogue: Science education through participatory and reflexive videography. Canadian Journal of Science, Mathematics and Technology Education, 14(2), 154-171.

Higgins, M. (2016). Decolonizing school science: Pedagogically enacting agential literacy and ecologies of relationships. In C. Taylor \& C. Hughes (Eds.), Posthuman Research Practices (pp. 267-289). Basingstoke, UK: Palgrave Macmillan. 
Kerr, J. (2017). How are we celebrating now? Engaging Eva Mackey's texts with Teacher Candidates at Canada's $150^{\text {th }}$. Paper presentation at Canadian Society for the Study of Education (CSSE) Meeting, Toronto, ON.

Madden, B. \& McGregor, H. (2013). Ex(er)cising student voice in pedagogy for decolonizing: Exploring complexities through duoethnography. Review of Education, Pedagogy and Cultural Studies, 35(5), 371-391.

Marker, M. (2006). After the Makah whalehunt: Indigenous knowledge and limits to multicultural discourse. Urban Education, 41(5), 482-505.

Truth and Reconciliation Commission of Canada (2015). Honouring the truth, reconciling for the future: Summary of the final report of the Truth and Reconciliation Commission of Canada. Retrieved from http://www.trc.ca/websites/trcinstitution/File/2015/Honouring the Truth Reconciling fo $\mathrm{r}$ the Future July 23 2015.pdf

University of British Columbia (UBC). (n.d.). həmləsəm and q’ələðən. Retrieved from http://vancouver.housing.ubc.ca/h\%C9\%99ml\%C9\%99s\%C9\%99m-andq $\%$ C $9 \% 991 \%$ C $9 \% 99 \%$ CF $\% 87 \%$ C $9 \% 99$ n-houses-at-totem-park/

Wherry, A. (2017, August 25). Should John A. Macdonald's name be removed from schools? It is at least a question worth asking. CBC News. Retrieved from http://www.cbc.ca/news/politics/john-a-macdonald-etfo-schools-analysis-aaron-wherry1.4260366 